\title{
Molecular detection of Leishmania spp. in cattle from Brazil by means of PCR using internal transcribed spacer 1
}

\author{
Detecção molecular de Leishmania spp. em gado no Brasil por PCR com espaçador interno transcrito 1
}

Geovanna Vioti' ${ }^{1}$; João Augusto Franco Leonel ${ }^{1}$; Kleber Menegon Lemes²; Vanessa Figueredo Pereira ${ }^{1}$; Helena Lage Ferreira ${ }^{1,3}$ (ㅇ); Lara Borges Keid ${ }^{1,3}$ (1); Ed Hoffman Madureira ${ }^{2}$; Rodrigo Martins Soares ${ }^{3}$ (1); Júlia Cristina Benassi ${ }^{3}$; Trícia Maria Ferreira de Sousa Oliveira ${ }^{1,3 *}$ (1)

\footnotetext{
${ }^{1}$ Programa de Pós-graduação em Epidemiologia Experimental Aplicada às Zoonoses, Faculdade de Medicina Veterinária e Zootecnia, Universidade de São Paulo - USP, Pirassununga, SP, Brasil

${ }^{2}$ Departamento de Reprodução Animal, Faculdade de Medicina Veterinária e Zootecnia, Universidade de São Paulo - USP, Pirassununga, SP, Brasil

${ }^{3}$ Departamento de Medicina Veterinária, Faculdade de Zootecnia e Engenharia de Alimentos, Universidade de Sáo Paulo - USP, Pirassununga, SP, Brasil
}

Received August 9, 2018

Accepted January 22, 2019

\begin{abstract}
Leishmania spp. are important agents of human and animal leishmaniases that have an important impact on public health. In this study, we aimed to detect the circulation of Leishmania spp. in cattle from a visceral leishmaniasis non-endemic area of the state of São Paulo, Brazil. DNA was extracted from blood samples from 100 heifers in the municipality of Pirassununga and was amplified using primers specific for the first internal transcriber spacer (ITS1), to assess the presence of trypanosomatids. The assays revealed that one sample presented bands of between 300 and 350 base pairs. In GenBank, this sample matched 100\% with Leishmania infantum (314 base pairs). The results suggest that cattle can be infected by Leishmania infantum in Brazil.
\end{abstract}

Keywords: Cattle, ITS1, Leishmania infantum, São Paulo.

\section{Resumo}

Leishmania spp. são agentes causadores das leishmanioses em humanos e em animais, gerando grande impacto à saúde pública. Este estudo objetivou detectar a circulação de Leishmania spp. em área não endêmica para leishmaniose visceral de São Paulo, Brasil. Foram extraídas amostras de DNA de 100 novilhas da cidade de Pirassununga. Estas amostras foram amplificadas com os iniciadores específicos para tripanosomatídeos Internal Transcriber Spacer 1 (ITS1). Os ensaios revelaram uma amostra com bandas entre 300 e 350 pares de base (pb). A amostra demonstrou 100\% de identidade com Leishmania infantum (314 pb). Os resultados sugerem que o gado pode ser infectado por L. infantum no Brasil.

Palavras-chave: Bovinos, ITS1, Leishmania infantum, São Paulo.

Leishmania infantum causes human and animal visceral leishmaniasis (VL) in Europe, North Africa and South America (ABRANTES et al., 2016). In Brazil, dogs are its major hosts and are targeted for visceral leishmaniasis control, along with sandflies of Lutzomyia sp., the vector for leishmania (BRASIL, 2014). However, a wide range of other possible reservoirs exists (WHO, 2015) including cats (OLIVEIRA et al., 2015; BENASSI et al., 2017) and horses (SOARES et al., 2013). As a result, cases of VL have sharply increased since the 1980s. Furthermore, cases of bovine infection by Leishmania spp. have been reported in Switzerland,

${ }^{*}$ Corresponding author: Trícia Maria Ferreira de Sousa Oliveira.

Departamento de Medicina Veterinária, Faculdade de Zootecnia e Engenharia

de Alimentos - FZEA, Universidade de São Paulo - USP, Avenida

Duque de Caxias Norte, 225, CEP 13635-900, Pirassununga, SP, Brasil.

e-mail: tricia@usp.br
China and India, while Leishmania spp. antibodies have been detected in cattle in Bangladesh and Zimbabwe (DUBEY et al., 1998; LOBSIGER et al., 2010; ALAM et al., 2011; SINGH et al., 2013; GAO et al, 2015). To date, no cases of $L$. infantum infecting cattle have been reported in non-endemic areas of Brazil. In the light of the high social, economic and health burdens brought by leishmaniasis, molecular methods of parasite detection and characterization have been developed to assist in disease treatment and control (DUNCAN, 2014).

The present study was conducted in the municipality of Pirassununga, state of São Paulo, Brazil, where VL does not occur endemically (BRASIL, 2018). Between 2014 and 2015, blood samples were donated from 100 heifers that were born on the Fernando Costa campus of the University of São Paulo (USP) at Pirassununga, São Paulo, Brazil. The samples were stored 
at $-20{ }^{\circ} \mathrm{C}$. This study was approved by the university's Ethics Committee for Animal Use (CEUA) under CEUA registration number 4580261017.

DNA extraction from blood samples was performed using a kit for DNA isolation from cells and tissues (Qiagen, USA), in accordance with the manufacturer's recommendations. The DNA thus extracted was stored at $-20{ }^{\circ} \mathrm{C}$ until analysis. All samples in this study were found to be positive for the endogenous $\beta$-actin gene, and this was determined as described by Manna et al. (2006), with analysis as described by Bustin et al. (2009).

PCR amplification for trypanosomatid detection was performed as described by El Tai et al. (2000), using the primers LITSR (5'-CTGGATCATTTTCCGATG-3') and L5-8S (5'-TGATACCACTTATCGCACTT-3'). These target ITS1 rRNA and amplify a segment that varies depending on the species (EL TAI et al., 2000; TENÓRIO et al., 2014). A DNA sample extracted from L. infantum (MCAN/BR/1984/CCC-17.481), which was provided by the Leishmaniasis Laboratory at the Oswaldo Cruz Institute (FIOCRUZ), Rio de Janeiro, was used as a positive control. To avoid contamination with the positive control, this sample was the last to be handled in all steps. DNA purification for sequencing was done from a second PCR reaction using a GE Healthcare kit (Illustra ${ }^{\circledR}$ GFX PCR DNA and gel band purification kit), before electrophoresis. The sequences were analyzed at the DNA sequencing service of the Human Genome and Stem Cell Research Center, Biological Institute (IB), USP. Chromatograms obtained with the forward and reverse primers were assembled with the Sequence Scanner Software 2 v2.2. The sequences were manipulated with Clustal W available in the BioEdit Sequence Alignment Editor version 7.1.11 (HALL, 1999). The assembled contigs were submitted to BLAST search (ALTSCHUL et al., 1990), and hit sequences were retrieved.

Blood samples donated from 100 heifers from the state of São Paulo, Brazil, were tested by means of PCR directed towards trypanosomatid ITS1. Serological tests could not be performed because we only received red blood cells. Only one sample was PCR-positive, yielding fragments ranging in size from 300 to $350 \mathrm{bp}$ (Figure 1). Direct sequencing and analysis of the amplicons revealed a sequence with $314 \mathrm{bp}$, which presented $100 \%$ matching with the L. infantum isolate 135 Hig ITS1 (accession number: MF977315.1).

Although our results only revealed one infected heifer among 100 animals tested, the potential of these animals to serve as Leishmania spp. parasite reservoirs is worrisome. Killick-Kendrick (1990) first pointed out that cattle were a potential reservoir for Leishmania spp. in India. A later study also pointed towards cattle, along with sheep, goats and donkeys, as the probable source of $L$. infantum that caused a VL outbreak in Jiash, China (GAO et al., 2015). The amplified kDNA from those farm animals matched Leishmania spp. isolates from human patients. Lastly, a more recent study revealed that bovine neutrophils and monocyte-derived macrophages (MDM) can be infected by $L$. donovani when co-incubated with its live promastigote (TASEW et al., 2016). Moreover, cattle herds contribute towards the environmental conditions and provide the food source that together allow development of the Leishmania spp. vector, i.e. the female sandfly (ROHOUSOVA et al., 2015).

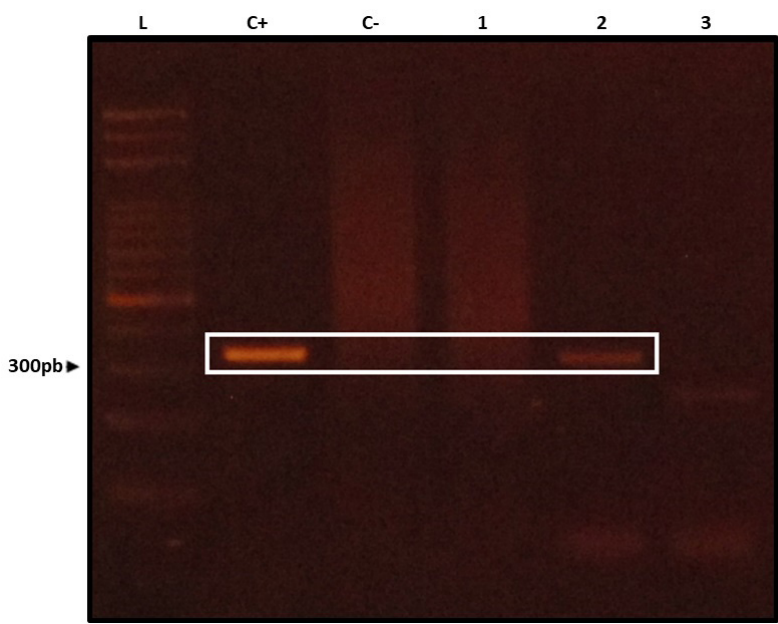

Figure 1. ITS1 blood sample from cattle showing positivity for trypanosomatids. (L) 100 bp ladder; (C+) DNA of L. infantum (MCAN/BR/1984/CCC-17.481) from positive control; (C-) negative control; (1, 3 and 4) bovine blood samples that were negative for L. infantum using ITS1; (2) L. infantum sample (314 bp) that was positive using ITS1.

Although cattle were found to provide only $0.6 \%$ of the blood source for Lutzomyia sp. in a rural area in Maranhão, Brazil, it was noted that this was nonetheless a valid blood source, thus providing a reminder that sand flies have opportunistic feeding habits (GUIMARÁES-E-SILVA et al., 2017). On the other hand, a study in Ethiopia showed that cattle were the second most preferred host of Phlebotomus orientalis (GEBRESILASSIE et al., 2015). The possibility that presence of cattle might be a risk factor for leishmaniasis in Brazil was discussed by Paixão (2017). However, from spatial analysis, this author concluded that their presence was actually a protective factor against VL in humans. According to this same author, this protective factor may occur due to the large extent of the area where these animals live, in comparison with the limited flight range of Lutzomyia spp. Following the same reasoning, our finding may be extremely important in small areas where humans, cattle, other animals and vectors share the same environment. Likewise, the presence of $L$. infantum in cattle also emphasizes the need for active surveillance to detect and diagnose infections in production animals.

No human VL cases have been reported in Pirassununga over the last ten years, but nine cases of cutaneous leishmanisis (CL) were reported over the same period (BRASIL, 2018). Brazil notified 19,402 cases of CL and 3,453 of VL to the World Health Organization in 2014 (WHO, 2016). According to Alvar et al. (2012), underreporting of leishmaniasis in Brazil is considered mild, since the degree of underreporting of VL was found to be between 1.3 and 1.7-fold.

These results suggest that $L$. infantum occurs and potentially circulates among cattle herds in the state of São Paulo, Brazil. Further studies should focus on the prevalence of this infection and on achieving better understanding of the epidemiology of leishmaniasis and the presence of clinical signs and metabolic changes in this animal population. Moreover, entomological and phylogenetical studies are fundamental for understanding the dynamics of transmission of these trypanosomatids in non endemic areas and in their hosts. 


\section{References}

Abrantes TR, Madeira MF, Silva DA, Perié CSFS, Mendes AAV Jr., Menezes RC, et al. Identification of canine visceral leishmaniasis in a previously unaffected area by conventional diagnostic techniques and cell-block fixation. Rev Inst Med Trop São Paulo 2016; 58: 3. http://dx.doi. org/10.1590/S1678-9946201658003. PMid:26910449.

Alam MS, Ghosh D, Khan MGM, Islam MF, Mondal D, Itoh M, et al. Survey of domestic cattle for anti-Leishmania antibodies and Leishmania DNA in a visceral leishmaniasis endemic area of Bangladesh. BMCVet Res 2011;7(1): 27. http://dx.doi.org/10.1186/1746-6148-7-27. PMid:21651757.

Altschul SF, Gish W, Miller W, Myers EW, Lipman DJ. Basic local alignment search tool. J Mol Biol 1990; 215(3): 403-410. http://dx.doi.org/10.1016/ S0022-2836(05)80360-2. PMid:2231712.

Alvar J, Vélez ID, Bern C, Herrero M, Desjeux P, Cano J, et al. Leishmaniasis worldwide and global estimates of its incidence. PLoS One 2012; 7(5): e35671. http://dx.doi.org/10.1371/journal.pone.0035671. PMid:22693548.

Benassi JC, Benvenga GU, Ferreira HL, Pereira VF, Keid LB, Soares R, et al. Detection of Leishmania infantum DNA in conjunctival swabs of cats by quantitative real-time PCR. Exp Parasitol 2017; 177: 93-97. http://dx.doi. org/10.1016/j.exppara.2017.04.004. PMid:28438522.

Brasil. Ministério da Saúde. Departamento de Vigilância Epidemilógica. Manual of surveillance and control of visceral leishmaniasis. Brasília: Secretaria de Vigilância em Saúde; 2014.

Brasil. Leishmaniose visceral: casos confirmados notificados no sistema de informação de agravos de notificação - 2007 a 2017 [online]. Brasília: Ministério da Saúde; 2018 [cited 2018 July 8]. Available from: http:// www2.datasus.gov.br/DATASUS/index.php?area $=02$

Bustin SA, Benes V, Garson JA, Hellemans J, Huggett J, Kubista M, et al. The MIQE guidelines: minimum information for publication of quantitative real-time PCR experiments. Clin Chem 2009; 55(4): 611-622. http://dx.doi. org/10.1373/clinchem.2008.112797. PMid:19246619.

Dubey JP, Bwangamoi O, Courtney SP, Fritz DL. Leishmania-like protozoan associated with dermatitis in cattle. J Parasitol 1998; 84(4): 865-867. http:// dx.doi.org/10.2307/3284607. PMid:9714228.

Duncan R. Advancing molecular diagnostics for trypanosomatid parasites. JMol Diagn 2014; 16(4): 379-381. http://dx.doi.org/10.1016/j. jmoldx.2014.04.001. PMid:24815378.

El Tai NO, Osman OF, El Fari M, Presber W, Schönian G. Genetic heterogeneity of ribosomal internal transcribed spacer in clinical samples of Leishmania donovani spotted on filter paper as revealed by single-strand conformation polymorphisms and sequencing. Trans R Soc Trop Med Hyg 2000; 94(5): 575-579. http://dx.doi.org/10.1016/S0035-9203(00)900932. PMid:11132393.

Gao CH, Wang JY, Zhang S, Yang YT, Wang Y. Survey of wild and domestic mammals for infection with Leishmania infantum following an outbreak of desert zoonotic visceral leishmaniasis in Jiashi, People's Republic of China. PLoS One 2015; 10(7): e0132493. http://dx.doi.org/10.1371/journal. pone.0132493. PMid:26177101.

Gebresilassie A, Yared S, Aklilu E, Kirstein OD, Moncaz A, Tekie H, et al. Host choice of Phlebotomus orientalis (Diptera: Psychodidae) in animal baited experiments: a field study in Tahtay Adiyabo district, northern Ethiopia. Parasit Vectors 2015; 8(1): 190. http://dx.doi.org/10.1186/ s13071-015-0807-4. PMid:25885333.
Guimarães-e-Silva AS, Silva SO, Silva RCR, Pinheiro VCS, Rebêlo JMM, Melo MN. Leishmania infection and blood food sources of phlebotomines in an area of Brazil endemic for visceral and tegumentary leishmaniasis. PLoS One 2017; 12(8): e0179052. http://dx.doi.org/10.1371/journal. pone.0179052. PMid:28837565.

Hall TA. Bioedit: a user-friendly biological sequence alignment editor and analysis program for Windows 9598 NT. Nucleic Acids Symp Ser 1999; 41: 95-98.

Killick-Kendrick R. Are cattle a reservoir host of kala-azar in India? Trans R Soc Trop Med Hyg 1990; 84(5): 754. http://dx.doi.org/10.1016/00359203(90)90181-D. PMid:2278094.

Lobsiger L, Müller N, Schweizer T, Frey CF, Wiederkehr D, Zumkehr B, et al. An autochthonous case of cutaneous bovine leishmaniasis in Switzerland. Vet Parasitol 2010; 169(3-4): 408-414. http://dx.doi.org/10.1016/j. vetpar.2010.01.022. PMid:20153118.

Manna L, Reale S, Viola E, Vitale F, Manzillo VF, Pavone LM, et al. Leishmania DNA load and cytokine expression levels in asymptomatic naturally infected dogs. Vet Parasitol 2006; 142(3-4): 271-280. http:// dx.doi.org/10.1016/j.vetpar.2006.06.028. PMid:16920264.

Oliveira TM, Pereira VF, Benvenga GU, Martin MF, Benassi JC, da Silva DT, et al. Conjunctival swab PCR to detect Leishmania spp. in cats. Rev Bras Parasitol Vet 2015; 24(2): 220-222. http://dx.doi.org/10.1590/S198429612015016 . PMid:26154963.

Paixão MS. Análise espacial e deteç̧ão de tripanosomatídeos em animais de produçâo de região endêmica para leishmaniose visceral [thesis]. Botucatu: Universidade Estadual Paulista; 2017.

Rohousova I, Talmi-Frank D, Kostalova T, Polanska N, Lestinova T, Kassahun A, et al. Exposure to Leishmania spp. and sand flies in domestic animals in northwestern Ethiopia. Parasit Vectors 2015; 8(1): 360. http:// dx.doi.org/10.1186/s13071-015-0976-1. PMid:26152578.

Singh N, Mishra J, Singh R, Singh S. Animal reservoirs of Visceral Leishmaniasis in India. J Parasitol 2013; 99(1): 64-67. http://dx.doi. org/10.1645/GE-3085.1. PMid:22765517.

Soares IR, Silva SO, Moreira FM, Prado LG, Fantini P, Maranhão RPA, et al. First evidence of autochthonous cases of Leishmania (Leishmania) infantum in horse (Equus caballus) in the Americas and mixed infection of Leishmania infantum and Leishmania (Viannia) braziliensis. Vet Parasitol 2013; 197(3-4): 665-669. http://dx.doi.org/10.1016/j.vetpar.2013.06.014. PMid:23845306.

Tasew G, Gadisa E, Abera A, Zewude A, Chanyalew M, Aseffa A, et al. In vitro permissiveness of bovine neutrophils and monocyte derived macrophages to Leishmania donovani of Ethiopian isolate. Parasit Vectors 2016; 9(1): 218. http://dx.doi.org/10.1186/s13071-016-1441-5. PMid:27090082.

Tenório MS, Sousa LO, Alves-Martin MF, Paixão MS, Rodrigues MV, Starke-Buzetti WA, et al. Molecular identification of trypanosomatids in wild animals. Vet Parasitol 2014; 203(1-2): 203-206. http://dx.doi. org/10.1016/j.vetpar.2014.02.010. PMid:24636787.

World Health Organization - WHO. Epidemiological situation [online]. 2015 [cited 2018 May 20]. Available from: https://www.who.int/ leishmaniasis/burden/en/

World Health Organization - WHO. Leishmaniasis in high-burden countries: an epidemiological update based on data reported in 2014. Wkly Epidemiol Rec 2016; 91(22): 285-296. 